ISSN 1392-3196 / e-ISSN 2335-8947

Zemdirbyste-Agriculture, vol. 108, No. 2 (2021), p. 109-116

DOI 10.13080/z-a.2021.108.014

\title{
Magnesium leaching processes from sod-podzolic sandy loam reclaimed by increasing doses of finely ground dolomite
}

\author{
Andrey LITVINOVICH ${ }^{1}$, Olga PAVLOVA ${ }^{1}$, Anton LAVRISHCHEV ${ }^{2}$, \\ Vladimir BURE ${ }^{1,3}$, Elmira SALJNIKOV ${ }^{4,5}$ \\ ${ }^{1}$ Agrophysical Research Institute \\ Grazhdanskya 14, 195220 St. Petersburg, Russia \\ ${ }^{2}$ St. Petersburg State Agrarian University \\ Peterburgskoye 2, Pushkin, 196601 St. Petersburg, Russia \\ ${ }^{3}$ St. Petersburg State University \\ Universitetskaya 7/9, 199034 St. Petersburg, Russia \\ ${ }^{4}$ Institute of Soil Science \\ Teodora Drajzera 7, 11000 Belgrade, Serbia \\ E-mail: soils.saljnikov@gmail.com \\ ${ }^{5}$ Mitscherlich Academy for Soil Fertility (MITAK) \\ Prof.-Mitscherlich-Alle 1, 14641 Paulinenaue, Germany
}

\begin{abstract}
The results of 8-variable column experiment on a strongly acidic sod-podzolic sandy loam reclaimed by the finely ground dolomite in a wide dose range are presented. The aim of the research was to measure and estimate leaching of magnesium $(\mathrm{Mg})$ and its migration pattern. The dolomite powder at the different doses calculated by hydrolytic acidity (Hy) was applied at 225, 337.5, 450, 675, 900, 1350 and $1800 \mathrm{mg}$, that corresponded to $0.5,0.75,1.0,1.5$, 2.0, 3.0 and 4.0 Hy, respectively. The migratory ability of $\mathrm{Mg}$ was studied in 12-times washing column experiment. Each washing was carried out by $400 \mathrm{ml}$ distilled water, simulating the volume of annual precipitation percolating through the soil stratum yearly. The increase in the amount of leaked moisture contributed to the enhancement of the eluvial losses of $\mathrm{Mg}$. The maximum loss of $\mathrm{Mg}$ due to migration was established in the filtrates of the first washing. As the dose of dolomite increased, the amount of the soil $\mathrm{Mg}$ migrating with the total amount of $\mathrm{Mg}$ decreased from $27 \%$ to $7.5 \%$. Complete removal of water-soluble $\mathrm{Mg}$ from the soil was not achieved in any of the studied treatments. Applied empirical estimations correctly described the process of leaching of $\mathrm{Mg}$ during repeated washing of the soil. Based on the data on the amount of leached $\mathrm{Mg}$ from soil reclaimed by a wide range of dolomite doses, a clustering of the empirical equations was performed. It was shown that in the $1^{\text {st }}$ stage of the experiment (from 1 to 4 washings) the rate of $\mathrm{Mg}$ leaching increased significantly with an increase in the dose of the dolomite. In the $2^{\text {nd }}$ stage ( 4 to 12 washings) such a pattern was not established. Depending on the dolomite dose applied, the losses of $\mathrm{Mg}$ increased from 14.05 to $50.6 \mathrm{mg}$ compared to $3.8 \mathrm{mg}$ in the non-limed (control) treatment.

The main finding is that finely ground dolomite in an amount exceeding a full dose calculated by 1 Hy applied to sod-podzolic forest soil resulted in unproductive losses of $\mathrm{Mg}$, i.e., with increasing dolomite dose, the losses of $\mathrm{Mg}$ increased.
\end{abstract}

Key words: clustering, empirical estimations, leaching rate, magnesium, migration.

\section{Introduction}

Magnesium $(\mathrm{Mg})$ is a vital element in crop production and in plant and animal nutrition (Cakmak, 2013; Yan, Hou, 2018) and health (Kisters, Gröber, 2013; Kong et al., 2020; Rosanoff, Kumssa, 2020) that is often underestimated. Soluble Mg in soil is prone to losses via leaching and plant uptake. It is generally accepted that

the high migration ability of calcium $(\mathrm{Ca})$ under the conditions of permanently and periodically washing water regime is explained by the large ionic radius $(1.06 \AA)$ of this element. This prevents $\mathrm{Ca}$ from participating in the construction of the crystal lattice of minerals (Sekine et al., 2017) and from firmly (non-exchangeable) fixing

Please use the following format when citing the article:

Litvinovich A., Pavlova O., Lavrishchev A., Bure V., Saljnikov E. 2021. Magnesium leaching processes from sodpodzolic sandy loam reclaimed by increasing doses of finely ground dolomite. Zemdirbyste-Agriculture, 108 (2): $109-116$. DOI 10.13080/z-a.2021.108.014 
to it and, therefore, it is more easily lost by leaching (Oliveira et al., 2002; Mikkelsen, 2010) or washing (Katutis, Rudzianskaite, 2015) compared to other cations (Maguire, Cowan, 2002; Mehmood et al., 2018). In addition, acidic soils have weak ability to retain cations, especially Mg (Wang et al., 2020), and particularly sodpodzolic soils weakly retain $\mathrm{Ca}$ (Bakina, 2012). To date, extensive information on the migration ability of $\mathrm{Ca}$ in soils with percolation water regime (Adomaitis et al., 2013; Shilnikov et al., 2013; Chandrakar et al., 2016; Pavlova et al., 2019; Wei et al., 2019; Costa et al., 2020; Rowley et al., 2020) including the empirical estimation of $\mathrm{Ca}$ leaching process (Litvinovich et al., 2020) is published. Although there is a large body of research on the role of $\mathrm{Mg}$ in plant nutrition, few studies have focused on the mechanisms of migration and loss of $\mathrm{Mg}$ from soil during leaching, and particularly the research on $\mathrm{Mg}$ migratory behaviour from dolomite amended soil is limited (Altland, Jeong, 2016), whilst the studies on the effect of finely ground dolomite powder on the pattern of $\mathrm{Mg}$ leaching is lacking.

The amount of $\mathrm{Mg}$ released from soil minerals is mostly small compared with the amounts needed to sustain high crop yield and quality (Senbayram et al., 2015). Therefore, for sustainable crop production on soils with limited plant-available $\mathrm{Mg}$ such as acid sodpodzolic soil, application of $\mathrm{Mg}$ fertilisers is important. Most of $\mathrm{Mg}$ fertilisers are divided into soluble and semisoluble sources. Dolomite $\left(\mathrm{MgCO}_{3} / \mathrm{CaCO}_{3}\right)$ typically containing $6 \%$ to $20 \% \mathrm{Mg}$ depending on the geologic source is considered as semi-soluble source of $\mathrm{Mg}$ (Mikkelsen, 2010). Dolomite lime may be used as a soil input to provide similar effects as agricultural lime, while supplying $\mathrm{Mg}$ in addition to $\mathrm{Ca}$. The rate of dolomite$\mathrm{Mg}$ dissolution largely depends on the particle size of lime material (Huang et al., 2007). Dolomite is often the least expensive common source of $\mathrm{Mg}$ but may be slow to dissolve, especially where soil acidity is lacking (Mikkelsen, 2010). Altland and Jeong (2016) revealed very low solubility of dolomite lime when plotting the $\mathrm{Ca}^{2+}+\mathrm{Mg}^{2+}$ solubility as a function of acidity $(\mathrm{pH})$, as $\mathrm{pH}$ increases above 6.5 , implying that above this $\mathrm{pH}$ level dolomite solubility ceases.

Contrary to $\mathrm{Ca}$, much fewer publications are devoted to the migration of Mg (Cakmak, 2013; Wang et al., 2020). Moreover, there are controversial results published by different researchers about the mobility of $\mathrm{Mg}$ compared to other soil cations. For example, Wang et al. (2020) recognize that mobility of $\mathrm{Mg}$ in soils is inferior to mobility of $\mathrm{Ca}$, because in his study, the amount of leached $\mathrm{Mg}$ from soil reclaimed by different doses of dolomite was 2-4 times less than Ca. This hypothesis was confirmed in the cotton irrigation experiment, where the eluvial loss of $\mathrm{Ca}$ exceeded the loss of $\mathrm{Mg}$ by 13.6 times (Litvinovich et al., 2020). In contrast, Gransee and Führs (2013) suggest that among soil cations Mg is more mobile, since its ionic radius is smaller than that of $\mathrm{Ca}$, $\mathrm{K}$ or $\mathrm{Na}$, while its hydrated radius is substantially larger (Maguire, Cowan, 2002). Since the migration intensity of $\mathrm{Mg}$ and the amount leached from soil profile depends of various soil-plant related factors (Gransee, Führs, 2013), these differences are most likely attributed to the different soil type and land use as well as analytical methodologies.

Three main geochemical barriers arise on the migration routes of $\mathrm{Mg}$ (Gransee, Führs, 2013): biogeochemical (absorption by living matter), silicate (formation of secondary minerals) and sorption (absorption by clay and humus colloids). However, these barriers are not able to completely prevent the loss of $\mathrm{Mg}$ from soils. Based on the long-term lysimetric studies, Shilnikov et al. (2013) established that soils with percolation type of water regime, regardless of the particle size distribution, lose 40-60 kg MgO per hectare per year in arable soils and $30-50 \mathrm{~kg}$ in meadows. Consequently, due to leaching and removal by agricultural plants, soils are gradually depleted in $\mathrm{Mg}$ resulting that the area of soils requiring the primary application of $\mathrm{Mg}$ in Russia is about 7 million ha (Zelenov et al., 2010).

Since 2011, in the Laboratory of Soil Amelioration of the Agrophysical Research Institute in St. Petersburg, Russia studies have been conducted aimed at establishing fertilising value and reclamation properties of the screening of dolomite used for road construction. Its effect on the decrease in mobility of phytotoxic $\mathrm{Fe}$ and $\mathrm{Mn}$ concentrations during liming was also studied (Litvinovich et al., 2019). The high efficiency of dolomite particles of different sizes was established when they were used for reclamation of acid soils. However, the mathematical estimation that adequately describes the process of leaching of $\mathrm{Mg}$ from soils reclaimed by dolomite is not known.

The aim of the study was estimation of Mg losses based on the data of the 8-variable column experiment to adequately describe the eluvial loss of $\mathrm{Mg}$ from sodpodzolic sandy loam reclaimed by finely ground dolomite in a wide dose range. The objectives included: 1) to determine the scale of $\mathrm{Mg}$ leaching during multiple (12) washing of the soil with a volume of water simulating the amount of atmospheric precipitation that annually seeps through the plough layer; 2) to establish the share of soil $\mathrm{Mg}$ in the total volume of the migrated $\mathrm{Mg}$ from the soil reclaimed by dolomite; 3 ) to make clustering of the migration patterns based on the obtained data; and 4) to calculate the average rate of leaching of $\mathrm{Mg}$ from nonlimed and limed soil at two stages of the experiment.

\section{Materials and methods}

The experiment was conducted in the summer of 2019 at the experimental fields of the St. Petersburg State Agrarian University, Pushkin, Russia. The object of the research was forest soil Albic Retisol (WRB, 2015), sod-podzolic sandy loam $(15.5 \%$ particle $<0.01 \mathrm{~mm})$ characterized by a low humus content $(1.2 \%)$ and a strongly acidic reaction $\left(\mathrm{pH}_{\mathrm{KCl}} 4.1\right)$. Hydrolytic acidity (Hy) was $3.0 \mathrm{mmol}$ equivalent $100 \mathrm{~g}^{-1}$ of soil, and the total content of calcium $(\mathrm{Ca})$ and magnesium $(\mathrm{Mg})$ amounts to $1.12 \%$ and $0.5 \%$ (Table 1 ).

For liming, finely ground dolomite powder was used, prepared from screening of dolomite passed through a sieve with a mesh diameter of $0.25 \mathrm{~mm}$. The used dolomite contained $48.1 \%$ of $\mathrm{CaCO}_{3}$ and $36.4 \%$ of $\mathrm{MgCO}_{3}$. The required dose of dolomite lime was calculated $0.5,0.75,1,1.5,2,3$ and $4 \mathrm{Hy}$. The experimental design was as follows: 1) no liming (control), $0.0 \mathrm{mg}$ dolomite;

Table 1. Chemical composition of sod-podzolic sandy loam (\%) in soil dried at $110^{\circ} \mathrm{C}$ temperature

\begin{tabular}{ccccccccccccccc}
\hline $\mathrm{SiO}_{2}$ & $\mathrm{TiO}_{2}$ & $\mathrm{Al}_{2} \mathrm{O}_{3}$ & $\mathrm{Fe}_{2} \mathrm{O}_{3}$ & $\mathrm{FeO}$ & $\mathrm{MnO}$ & $\mathrm{MgO}$ & $\mathrm{CaO}$ & $\mathrm{K}_{2} \mathrm{O}$ & $\mathrm{Na}_{2} \mathrm{O}$ & $\mathrm{P}_{2} \mathrm{O}_{5}$ & i.1. & $\mathrm{S}$ & $\mathrm{H}_{2} \mathrm{O}$ & $\sum$ \\
\hline 75.73 & 0.50 & 9.81 & 1.52 & 0.78 & 0.09 & 0.50 & 1.12 & 2.67 & 1.14 & 0.16 & 6.53 & $<0.05$ & 1.12 & 99.7 \\
\hline
\end{tabular}

i.l. - ignition losses 
liming at: 2) $0.5 \mathrm{Hy}$ (corresponding to $225.0 \mathrm{mg}$ of dolomite), 3) 0.75 Hy (337.5 mg), 4) $1.0 \mathrm{Hy}$ (450.0 mg), 5) $1.5 \mathrm{Hy}(675.0 \mathrm{mg}), 6) 2.0 \mathrm{Hy}(900.0 \mathrm{mg}), 7) 3.0 \mathrm{Hy}$ $(1350.0 \mathrm{mg})$ and 8$) 4.0 \mathrm{Hy}(1800.0 \mathrm{mg})$. The amount of liming ameliorant dolomite corresponding to 2-4 full doses calculated by Hy usually is not used in practice, because such an accumulation of lime in some parts of the field can occur with uneven spreading of lime (Litvinovich et al., 2019).

The air-dry soil was sieved through a $1 \mathrm{~mm}$ holed mesh, then was limed with a strictly calculated amount of finely ground dolomite and placed in glasses upon moistening with distilled water. Composting was carried out at $28^{\circ} \mathrm{C}$ temperature in a thermostat KS 200 (Special Design and Technological Bureau of Program Control Systems, Russia), stirring regularly. The duration of the experiment was 30 days. Soil moisture throughout the composting period was maintained at $60 \%$ of the total field moisture capacity. At the inlet and at the outlet, the water volume was measured as follows: the soil in the airdry state was saturated to the full field moisture capacity (FMC). This indicator is taken as $100 \%$ soil moisture. Next, the moisture content was calculated as $60 \%$ FMC. During the composting of the soil in the thermostat, the humidity was maintained at $60 \%$ FMC. For this, the soil in the vessel was removed from the thermostat once a day and weighed. According to the decrease in the mass of evaporated moisture, the required volume of water was set, which was added to the vessel while stirring.

The washings were carried out by a strictly calculated quantity of distilled water of $400 \mathrm{ml}$ simulating an annual precipitation percolating through the soil stratum. After infiltration and one day break, the washing was repeated. The calculations were based on the data of mean annual precipitation in the Northwest of Russia that is around $600 \mathrm{~mm}$, and transpiration by plants and evaporation from the soil surface that is around $400 \mathrm{~mm}$ (http://www.meteo.nw.ru/articles/index.php?id=2). Thus, annually $200 \mathrm{~mm}$ of precipitation percolates through the soil stratum. The amount of water required for a single wash of one column was calculated from the formula:

$$
V=\frac{\left(\pi \times r^{2} \times 200\right)}{1000}
$$

where $\pi=3.14, r$ is column radius, $\mathrm{mm}, 1000$ - transition to $\mathrm{ml}$. According to the formula, for one washing, $400 \mathrm{ml}$ of water was used.

After composting, the soil was removed from the glasses, dried and placed in separatory funnels. The mass of soil in the funnel was $300 \mathrm{~g}$, the height of the soil layer was $17 \mathrm{~cm}$, and the density of soil packing in the funnel was $1.0-1.1 \mathrm{~g} \mathrm{~cm}^{-3}$.

Recalculation of the dose of lime from hectare to 1 column was carried out on the assumption that the mass of arable $0-20 \mathrm{~cm}$ soil layer per 1 ha is 3000 tons. This column method proved to be successfully used widely for analysing leaching mechanisms of different elements from soil under simulated rainfall (Costa et al., 2020).

Initially, the soil in the funnel was saturated with distilled water until the first drop of leaked moisture appeared, followed by washing. Between each washing, one-day break was included, so in total 12 washes (12 washing times) were conducted. The amount of distilled water for one wash was $400 \mathrm{ml}$. The total amount of leaked moisture was 4.8 litres. The duration of the experiment was $\sim 2.5$ months. The break between individual washings was not more than 1-2 days. The $\mathrm{Mg}$ content was determined in each portion of the filtrate on an atomic adsorption spectrophotometer (Shimadzu, Japan).

The data were statistically processed using regression analysis and clustering (Bure, Parilina,
2013). Clustering was carried out based on the analysis of the curves calculated empirically, after which it was confirmed on the basis of a comparative analysis of the introduced numerical characteristics.

\section{Results and discussion}

The data on magnesium $(\mathrm{Mg})$ content in the filtered elutes of an individual washing for the experimental period are presented in Figure 1.

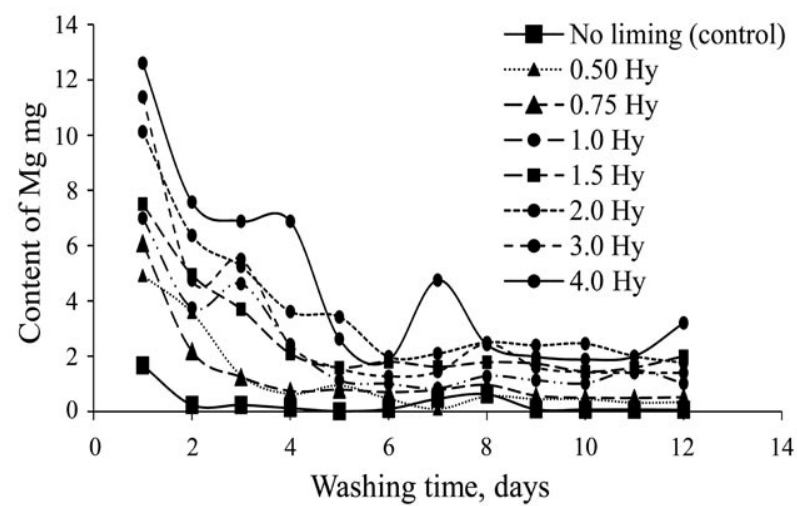

Figure 1. Content of leached magnesium $(\mathrm{Mg})$ from acid sod-podzolic soil as influenced by different hydrolytic acidity (Hy) doses of dolomite

It was established that in the non-limed (control) treatment $\mathrm{Mg}$ was present in the leachate of every washing. The maximum losses occurred at the first wash. The absolute amount of $\mathrm{Mg}$ washed in the first portion of the filtrate was $1.67 \mathrm{mg}$, which corresponded to $44 \%$ of the total amount washed in 12 washings. An increase in the amount of leaking moisture leads to an increase in migration losses of $\mathrm{Mg}$. In the filtrate of the second washing, the content of leached $\mathrm{Mg}$ sharply decreased to $0.24 \mathrm{mg}$. The complete removal of water-soluble $\mathrm{Mg}$ from the soil of the non-limed (control) treatment was not achieved in the entire 12 washings. Our findings suggesting that the highest losses of $\mathrm{Mg}$ occurred at the first washing (i.e., raining) agree with those of Royani et al. (2018), who found that Mg extraction from calcined dolomite ore increases rapidly with the rise in liquid to solid ratio for $3 \mathrm{~h}$, where the $\mathrm{Mg}$ extraction reaches $98.82 \%$ with liquid to solid ratio of $20 \mathrm{~mL} \mathrm{~g}^{-1}$.

In the treatments with addition of dolomite, the amount of migrated $\mathrm{Mg}$ increased: the higher the dose of dolomite, the higher the eluvial loss was. Compared with the dose corresponding to $1 \mathrm{Hy}$, an increase in the dose of dolomite by 2-4 times the migratory mobility of $\mathrm{Mg}$ increased by 1.6-1.9 times. The total amount of leached $\mathrm{Mg}$ ranged from 3.6 to $50.6 \mathrm{mg}$ for 12 washings. The filtrates of the first wash were characterized by a maximum concentration of $\mathrm{Mg}$. Depending on the treatment, the proportion of leached $\mathrm{Mg}$ during the first wash was $23-44 \%$ of the total amount of $\mathrm{Mg}$ washed over the experimental period. In the leachate of the second washing, the Mg content sharply decreased. Further, as the experiment was carried out, from 3 to 12 washing the concentration of $\mathrm{Mg}$ in all treatments decreased gradually. These results support findings of Liu et al. (2019) stating that with application of $\mathrm{Mg}$ fertiliser $\mathrm{Mg}$ leaching loss is increased linearly with applied dose of fertiliser.

Although the pathway for $\mathrm{Mg}$ is the same as Ca, many researchers (Gardner, 2004; Gransee, Führs, 2013; Senbayram et al., 2015; Jones, 2016) showed that $\mathrm{Mg}$ is a highly mobile element, since it is less linked to soil charges resulting in its higher leaching from 
soil. In our experiment, addition of Mg-containing finely ground dolomite obviously resulted in its accelerated leaching. Typically, $\mathrm{Mg}$ adsorbed on the surfaces of mineral particles is rapidly replaced by other cations present in soil solution stoichiometrically (Mikkelsen, 2010).

If it is assumed that the amount of leached $\mathrm{Mg}$ is constant and does not depend on the amount of dolomite used, then with an increase in the dose of lime the proportion of the $\mathrm{Mg}$ leached from soil gradually decreases from $27 \%$ to $7.5 \%$ in the total volume of the migrated element. This implies that when using finely ground dolomite in an amount exceeding the scientifically substantiated (1 Hy) dose, the unproductive losses of $\mathrm{Mg}$ are amplified suggesting that the higher the dose of lime, the unproductive loss of $\mathrm{Mg}$ is greater. The effect of the size of liming material on dissolution rate was established earlier (Litvinovich et al., 2019), which is controlled by a surface area reaction (Kamprath, Smyth, 2005), i.e., the more potentially reactive surface a particle has, the quicker it can dissolve (Jones, 2016).

For empirical approximation of the dynamics of $\mathrm{Mg}$ leaching from soil for the experimental period, the data were logged and the logarithms of empirical equations were constructed based on polynomials of the third degree. The equations describing the dynamics of the $\mathrm{Mg}$ content in individual treatments of the experiment are given in Table 2. All 8 empirical equations have very high statistical significance ranging between 0.000004 and $<0.05$.

Table 2. Empirical equations of magnesium $(\mathrm{Mg})$ migration from soil reclaimed by different doses of dolomite

\begin{tabular}{clr}
\hline Treatment & \multicolumn{1}{c}{ Empirical equation } & $p$ value for Fisher criterion \\
\hline No liming (control) & $\ln \left(y_{1}\right)=1.78-1.92 t+0.31 t^{2}-0.016 t^{3}$ & 0.05 \\
$0.50 \mathrm{Hy}$ & $\ln \left(y_{2}\right)=2.91-1.2 t+0.12 t^{2}-0.004 t^{3}$ & 0.005 \\
$0.75 \mathrm{Hy}$ & $\ln \left(y_{3}\right)=2.79-1.27 t+0.17 t^{2}-0.007 t^{3}$ & 0.00004 \\
$1.00 \mathrm{Hy}$ & $\ln \left(y_{4}\right)=2.72-0.73 t+0.06 t^{2}-0.0015 t^{3}$ & 0.0006 \\
$1.50 \mathrm{Hy}$ & $\ln \left(y_{5}\right)=2.7-0.71 t+0.071 t^{2}-0.002 t^{3}$ & 0.00001 \\
$2.00 \mathrm{Hy}$ & $\ln \left(y_{6}\right)=2.93-0.65 t+0.068 t^{2}-0.0025 t^{3}$ & 0.00001 \\
$3.00 \mathrm{Hy}$ & $\ln \left(y_{7}\right)=3.38-1.04 t+0.12 t^{2}-0.005 t^{3}$ & 0.00035 \\
$4.00 \mathrm{Hy}$ & $\ln \left(y_{8}\right)=3.12-0.64 t+0.054 t^{2}-0.001 t^{3}$ & 0.0043 \\
\hline
\end{tabular}

Hy - the hydrolytic acidity used for calculation of the lime dose; $\mathrm{t}$ - time, $y_{i}$; the $p$-value for Fisher criterion

The graphs of the empirical equations are shown in Figure 2. The obtained equations can be divided into four groups: 1) equation (1); the graph of this equation does not intersect with other graphs; 2) equations (2) and (3); the graphs of these equations are separated from all other graphs and intersect each other; 3 ) equation (4); the graph of this equation does not intersect with other graphs; 4) equations (5-8); the graphs of these equations intersect and are located close to each other.

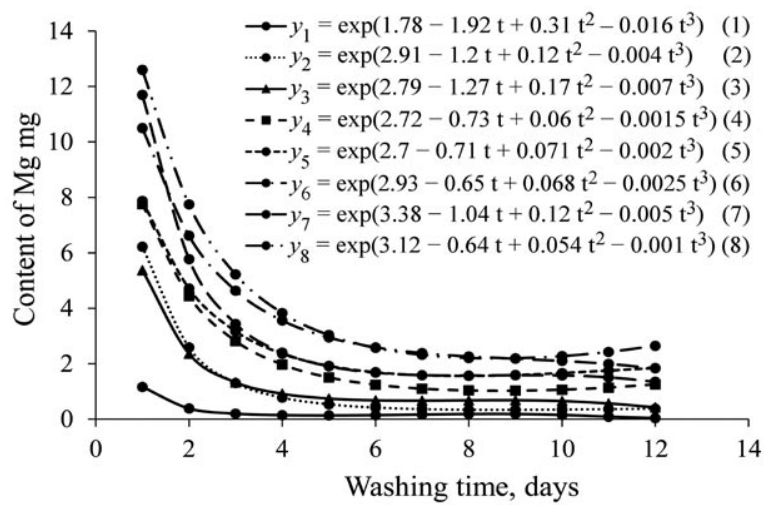

Figure 2. Curves of empirical equations of magnesium $(\mathrm{Mg})$ migration mobility over the experimental period

In Figure 2, empirical equations form four disjoint clusters are shown. For a more formal explanation of the clustering, the following numerical characteristic was introduced. For each equation, the sum of the values of the logarithms of the equation for all 12 washings was found:

$$
\begin{aligned}
& \mathrm{s}_{1}=\sum_{(\mathrm{t}=1)}^{12} \ln \left(y_{1}(t)\right)=21.168 \\
& \mathrm{~s}_{2}=\sum_{(\mathrm{t}=1)}^{12} \ln \left(y_{2}(t)\right)=-4.967 \\
& \mathrm{~s}_{3}=\sum_{(\mathrm{t}=1)}^{12} \ln \left(y_{3}(t)\right)=-0.991 \\
& \mathrm{~s}_{4}=\sum_{(\mathrm{t}=1)}^{12} \ln \left(y_{4}(t)\right)=6.44 \\
& \mathrm{~s}_{5}=\sum_{(\mathrm{t}=1)}^{12} \ln \left(y_{5}(t)\right)=9.85
\end{aligned}
$$

$$
\begin{aligned}
& \mathrm{s}_{6}=\sum_{(\mathrm{t}=1)}^{12} \ln \left(y_{6}(t)\right)=13.57 \\
& \mathrm{~s}_{7}=\sum_{(\mathrm{t}=1)}^{12} \ln \left(y_{7}(t)\right)=10.02 \\
& \mathrm{~s}_{8}=\sum_{(\mathrm{t}=1)}^{12} \ln \left(y_{8}(t)\right)=14.73
\end{aligned}
$$

The calculated values of the introduced characteristic confirm the correctness of the clustering. The sum $\mathrm{s}_{1}=-21.168$ (included in the cluster I) is very different from the sums $\mathrm{s}_{2}=-4.967$ and $\mathrm{s}_{3}=-0.991$ (included in the cluster II). All sums from the clusters I and II take negative values, while the sums from the III and IV ones are positive. The sum $\mathrm{s}_{4}=6.44$ is positive and significantly different from the next largest sum, so it should be attributed to the cluster III. All other amounts $\mathrm{S}_{5}, \mathrm{~s}_{6}, \mathrm{~S}_{7}$ and $\mathrm{s}_{8}$ (included in the cluster IV) are very different from the sums from the clusters I, II and III and differ little among themselves. The clustering of the migration pattern of $\mathrm{Mg}$ from the acid forest soil as affected by different doses of dolomite confirmed that the unproductive losses of $\mathrm{Mg}$ with the migrating water increases with the increase of the dose of dolomite.

One of the research objectives was to establish the rate of $\mathrm{Mg}$ leaching from the soil of individual treatments. The experimental results showed that regardless of the type of experiment the process of leaching of $\mathrm{Mg}$ can be divided into two stages. The rate of $\mathrm{Mg}$ leaching in the $1^{\text {st }}$ stage of the experiment is much greater than in the $2^{\text {nd }}$ one. The $1^{\text {st }}$ stage is characterized by rapid leaching of Mg: 1-3 washings for the non-limed (control) and 1-4 times - for the rest of the treatments; the $2^{\text {nd }}$ stage is from 4 to 12 times. The construction of empirical curves was carried out separately for each of the stages. To develop empirical equations, paired linear regression was used. The empirical equations and the average rate of $\mathrm{Mg}$ losses from the soil of various treatments at each stage of the experiment are given in Table 3.

The data of the Table 3 show that at the $1^{\text {st }}$ stage of the experiment, when the dose of dolomite was increased, the rate of $\mathrm{Mg}$ leaching also increased. In the non-limed (control) treatment, it amounted to $0.7175 \mathrm{mg}$, while in 
Table 3. Empirical equations of magnesium $(\mathrm{Mg})$ leaching rate at two stages of the experiment

\begin{tabular}{cll}
\hline \multirow{2}{*}{ Treatment } & \multicolumn{2}{c}{ Empirical equations } \\
\cline { 2 - 3 } No liming (control) & \multicolumn{1}{c}{$1^{\text {st }}$ stage } & $2^{\text {nd }}$ stage \\
$0.50 \mathrm{Hy}$ & $y_{1.1}=2.15-0.7175 t$ & $y_{1.2}=0.276-0.0115 t$ \\
$0.75 \mathrm{Hy}$ & $y_{2.1}=6.39-1.5 t$ & $y_{2.2}=0.83-0.045 t$ \\
$1.00 \mathrm{Hy}$ & $y_{3.1}=6.798-1.69 t$ & $y_{3.2}=0.994-0.04 t$ \\
$1.50 \mathrm{Hy}$ & $y_{4.1}=7.665-1.287 t$ & $y_{4.2}=1.81-0.069 t$ \\
$2.00 \mathrm{Hy}$ & $y_{5.1}=8.925-1.745 t$ & $y_{5.2}=1.87-0.016 t$ \\
$3.00 \mathrm{Hy}$ & $y_{6.1}=11.495-2.06 t$ & $y_{6.2}=3.9-0.174 t$ \\
$4.00 \mathrm{Hy}$ & $y_{7.1}=12.56-2.619 t$ & $y_{7.2}=2.19-0.067 t$ \\
& $y_{8.1}=14.965-2.995 t$ & $y_{8.2}=3.039-0.05 t$ \\
\hline
\end{tabular}

$\mathrm{Hy}$ - the hydrolytic acidity used for calculation of the lime dose; $\mathrm{t}$ - the washing time

the treatment using 4 full doses calculated according to $\mathrm{Hy}$, it increased to $2.995 \mathrm{mg}, 1^{\text {st }}$ stage included 1 to 3 (4) washings and $2^{\text {nd }}$ stage included $4(5)$ to 12 washings. According to the magnitude of the $\mathrm{Mg}$ leaching rate at the $1^{\text {st }}$ stage, the treatments can be divided into four clusters: the cluster I includes the equation of treatment 1 (control), the $\mathrm{Mg}$ leaching rate at the $1^{\text {st }}$ stage is minimal: $v_{1.1}=0.7175$; the cluster II includes the equations of the treatments 2, 3 and 4; the $\mathrm{Mg}$ leaching rate in the $1^{\text {st }}$ stage: $v_{2.1}=1.5, v_{3.1}=1.69$ and $v_{4.1}=1.287$, is significantly higher than in the treatment 1 , but significantly less than in 5, 6, 7 and 8 ones; the cluster III includes treatments 5 and 6 , where the $\mathrm{Mg}$ leaching rate in the $1^{\text {st }}$ stage: $v_{51}$ $=1.745$ and $v_{61}=2.06$, is significantly higher than in the treatments 1, 2, 3 and 4, but significantly less than in the 7 and 8 ones; the cluster IV includes treatments 7 and 8 , where the $\mathrm{Mg}$ leaching rate in the $1^{\text {st }}$ stage: $v_{7.1}=2.619$ and $v_{81}=2.995$, significantly exceed the leaching rate in all other treatments.
The results of our experiment indicate that $\mathrm{Mg}$ is weakly bound to exchange sites (Kamprath, Smyth, 2005) due lower molecular weight (Jones, 2016) than other cations and thus easier leaches from soil solution. This was particularly proved in our study, when due to slower reaction rate of finely ground limestone particles, the $\mathrm{Mg}$ from the amended dolomite has migrated faster and easier from soil solution.

Table 4 shows the data for empirical equations of the paired linear regression between the rate of $\mathrm{Mg}$ leaching at the $1^{\text {st }}$ stage of the experiment and the dose of dolomite (control treatment corresponds to a dose of $\mathrm{x}=0$ ). The dose of dolomite is given in absolute units (variable $\mathrm{x}_{1}, \mathrm{mg}$ ), and the average rate in the $1^{\text {st }}$ stage (column 4) shows the calculated values according to the empirical equation:

$$
v=1.003+0.001149 \times x_{1}
$$

Table 4. The relationship between the applied dose of dolomite and the rate of magnesium $(\mathrm{Mg})$ leaching at two stages of the experiment

\begin{tabular}{|c|c|c|c|c|c|}
\hline \multirow{3}{*}{ Treatment } & \multirow{3}{*}{$\begin{array}{c}\text { Dose of } \\
\text { dolomite } \\
\text { mg }\end{array}$} & \multicolumn{4}{|c|}{ Empirical equations } \\
\hline & & $1^{\text {st }}$ stage & & $2^{\text {nd }}$ stage & \\
\hline & & $\begin{array}{c}\text { estimated equation } \\
\text { values }\end{array}$ & $\begin{array}{c}\text { average rate } \\
(v)\end{array}$ & $\begin{array}{c}\text { estimated equation } \\
\text { values }\end{array}$ & $\begin{array}{c}\text { average rate } \\
(v)\end{array}$ \\
\hline No liming (control) & 0.0 & 1.002590742 & 0.718 & 0.041370018 & 0.0115 \\
\hline $0.50 \mathrm{Hy}$ & 225.0 & 1.261130901 & 1.500 & 0.046920601 & 0.045 \\
\hline $0.75 \mathrm{Hy}$ & 337.5 & 1.390400981 & 1.690 & 0.049695892 & 0.040 \\
\hline $1.00 \mathrm{Hy}$ & 450.0 & 1.519671061 & 1.287 & 0.052471183 & 0.069 \\
\hline $1.50 \mathrm{Hy}$ & 675.0 & 1.778211220 & 1.745 & 0.058021766 & 0.016 \\
\hline $2.00 \mathrm{Hy}$ & 900.0 & 2.036751380 & 2.060 & 0.063572348 & 0.185 \\
\hline $3.00 \mathrm{Hy}$ & 1350.0 & 2.553831698 & 2.619 & 0.074673513 & 0.067 \\
\hline $4.00 \mathrm{Hy}$ & 1800.0 & 3.070912017 & 2.995 & 0.085774678 & 0.050 \\
\hline
\end{tabular}

Hy - the hydrolytic acidity used for calculation of the lime dose

Table 4 shows the data for empirical equations of the paired linear regression between the rate of $\mathrm{Mg}$ leaching at the $2^{\text {nd }}$ stage of the experiment and the dose of dolomite (control treatment corresponds to a dose $\mathrm{x}=0$ ). The dose of dolomite is given in absolute units (variable $\mathrm{x}_{1}, \mathrm{mg}$ ), and the average rate in the $2^{\text {nd }}$ stage (column 6) shows the calculated values according to the empirical equation:

$$
v=0.041+0.000025 \times x_{1}
$$

The empirical equation (10) is not statistically significant, $p$-value $(F)=0.5$ and the coefficient of determination $R^{2}=0.087$.

The empirical equation (9) is significant at a very high level of significance with $p$-value $(F)=$ 0.00016 and the coefficient of determination $R^{2}=0.92$
(Figure 3A). The very high statistical significance of empirical equation (9) means that according to the experimental data the rate of $\mathrm{Mg}$ leaching at the $1^{\text {st }}$ stage increases significantly with an increase in the dose of dolomite suggesting a statistically significant tendency for a monotonous increase in $\mathrm{Mg}$ leaching, as the dose of lime increases.

According to the magnitude of the rate of $\mathrm{Mg}$ leaching at the $2^{\text {nd }}$ stage, the treatments can be divided into three clusters: the cluster I includes treatments 1 (control) and 5, where the $\mathrm{Mg}$ leaching rate in $2^{\text {nd }}$ stage: $v_{1.2}=0.0115$ and $v_{5.2}=0.016$, were minimal; the cluster II includes treatments 2, 3, 4, 7 and 8, where the Mg leaching rate in $2^{\text {nd }}$ stage: $v_{22}=0.045, v_{32}=0.04, v_{42}=0.069, v_{72}$ $=0.067$ and $v_{82}=0.05$, respectively, were significantly greater than in the treatments 1 and 5, but significantly less 

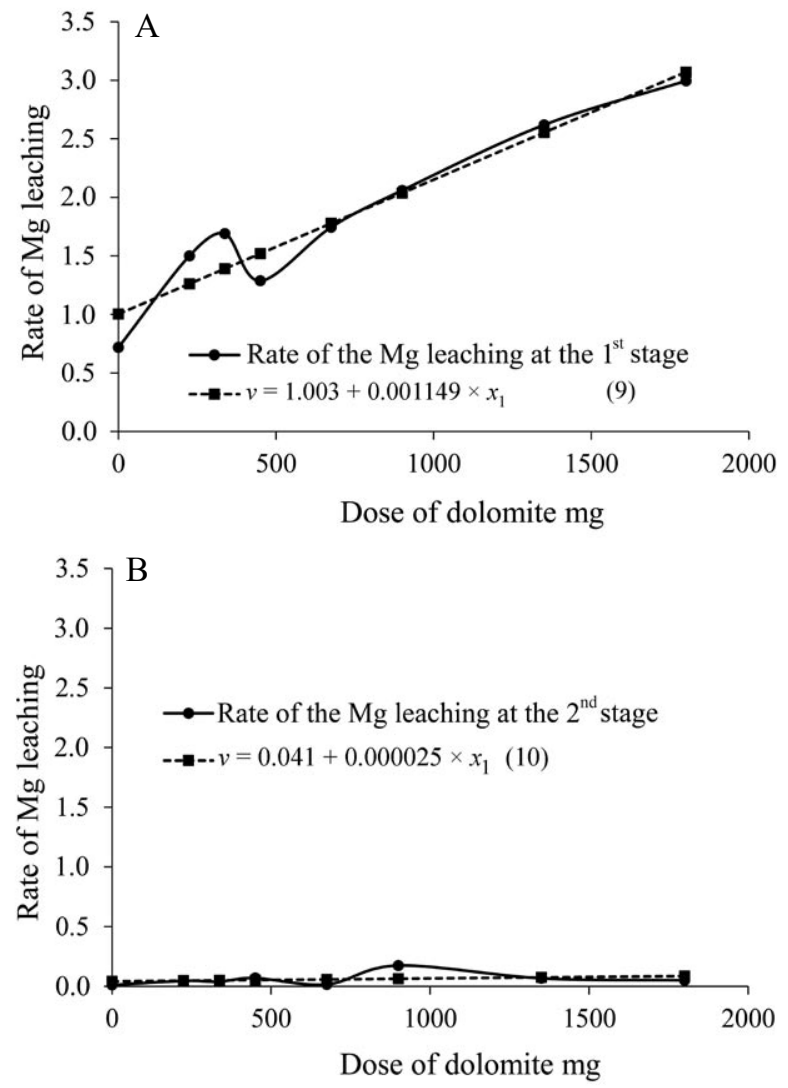

Figure 3. Dependence of the rate of magnesium $(\mathrm{Mg})$ leaching on the dose of dolomite at $1^{\text {st }}(\mathrm{A})$ and $2^{\text {nd }}(\mathrm{B})$ stages of the experiment

than in the treatment 6 ; the cluster III includes treatment 6 , where the $\mathrm{Mg}$ leaching rate in $2^{\text {nd }}$ stage: $v_{6.2}=0.174$, was significantly higher than in all other treatments. Because the variations between the rate of $\mathrm{Mg}$ leaching in the $2^{\text {nd }}$ stage were insignificant, their clustering was more empirical and showed the trend of the process rather than explaining the differences. The observed higher rate at the 6 washing of the $2^{\text {nd }}$ stage was most likely associated with specific characteristics of the plot.

The rate of $\mathrm{Mg}$ leaching at the $2^{\text {nd }}$ stage of the experiment did not show statistically significant dependence of the monotonic nature between the rate of leaching of $\mathrm{Mg}$ and an increase in the dose of dolomite. In general, the rate of $\mathrm{Mg}$ leaching at the $1^{\text {st }}$ stage was completely determined by the dose of dolomite. The rate of $\mathrm{Mg}$ leaching at $2^{\text {nd }}$ stage was insignificantly dependent on the dose of the dolomite.

The pattern of $\mathrm{Mg}$ leaching from forest soil obviously differs from that on arable lands. Results of numerous studies (Loganathan et al., 1999; Mitchell et al., 2000; Härdter et al., 2004) showed that Mg leaching in crop lands is minimal or negligible. The statements were based on the fact that dolomite slowly releases $\mathrm{Mg}$ thus preventing its losses through leaching, particularly in acidic soils (Härdter et al., 2004). However, as shown by the results of our experiment, in a natural forest landscape, the $\mathrm{Mg}$ applied with finely ground dolomite leached most at the beginning of the washing experiment, which simulated rain precipitation. When the amount of $\mathrm{Mg}$ leaching from soil exceeds the rate of release of $\mathrm{Mg}$ from dolomite, the concentration of $\mathrm{Mg}$ in the solution and at the exchange sites will decrease. This situation together with a competition with other cations can result in low-Mg availability for plants (Mikkelsen, 2010), since as demonstrated by our results, over time $\mathrm{Mg}$ actively migrates from the soil under rain precipitation.

Leda and Wright (1991) found that higher doses of dolomite produced an unnecessary increase in leachate electrical conductivity and, therefore, adversely affected plant quality, due to acidifying effect. Obviously, in our experiment the finely ground dolomite affected the rate of $\mathrm{Mg}$ leaching from soil solution. In similar experiments, Jones (2016) found that particle size of liming material influenced the speed of reaction, where the finer materials provided greater surface area to react in a given volume of soil and may have influenced the maximum $\mathrm{pH}$ reached. Typically, when acidic soils are used for crop production, the nutrient requirements of the individual crops are considered.

However, when an acid sod-podzolic soil is used for growing crops, it is recommended to balance the $\mathrm{Mg}$ input from the ameliorant with leaching and runoff with consideration of the particle size of applied dolomite amendment.

\section{Conclusions}

1. The results of the present study showed that when finely ground dolomite in an amount exceeding a full dose calculated by hydrolytic acidity (1 Hy) dose was applied to sod-podzolic forest soil, the unproductive losses of magnesium $(\mathrm{Mg})$ were amplified, i.e., with increasing dose of lime the unproductive loss of $\mathrm{Mg}$ increased.

2. The conventionally accepted statement that $\mathrm{Mg}$ from dolomite dissolves slowly supplying plants with Mg-nutrient for longer period is probably true for the raw-ameliorant dolomite. The results of our experiment showed that when dolomite stone was finely ground and added to the sod-podzolic forest soil, it was quickly washed out from the soil by seeping water.

3 . The obtained results and conclusions were confirmed by the estimated empirical equations with a high probability, which made it possible to group the results of $\mathrm{Mg}$ migration depending on the rate of $\mathrm{Mg}$ leaching. The results of this experiment provide additional insights into the effect of finely ground dolomite on $\mathrm{Mg}$ losses, which is useful for proper management of acidic soils.

\section{Acknowledgments}

Preparation of this manuscript was partially supported by the Ministry of Education, Science and Technological Development of the Republic of Serbia, contract No. 451-03-68/2020-14.

Received 20072020

Accepted 20012021

\section{References}

Adomaitis T., Staugaitis G., Mažvila J., Vaišvila Z., Arbačiauskas J., Lubytė J., Šumskis D., Švėgžda A. 2013. Leaching of base cations as affected by a forty-year use of mineral fertilization. Zemdirbyste-Agriculture, 100 (2): 119-126. https://doi.org/10.13080/z-a.2013.100.015

Altland J. E., Jeong K. Y. 2016. Dolomitic lime amendment affects pine bark substrate $\mathrm{pH}$, nutrient availability, and plant growth: a review. HortTechnology. 26 (5):565-573. https://doi.org/10.21273/HORTTECH03465-16 
Bakina L. 2012. Role of fractions of humus substances in soil and environmental processes: doctoral dissertation. St. Petersburg State University, Russia, 397 p. (in Russian).

Bure V. M., Parilina E. M. 2013. Probability theory and mathematical statistics. St. Petersburg, Russia, 416 p. (in Russian).

Cakmak I. 2013. Magnesium in crop production, food quality and human health. Plant and Soil, 368: 1-4. https://doi.org/10.1007/s11104-013-1781-2

Chandrakar T., Jena D., Dash A. K., Rout K. K., Panda N. 2016. Leaching behaviour of calcium through soil columns treated with lime, gypsum and fly ash. Ecology, Environment and Conservation, 22 (1): 319-323.

Costa C. F. F. A., Mesquita L. S., Rocha F. V., Mesquita R. B. R. Rangel A. O. S. S. 2020. Exploiting flow analysis as a tool for monitoring the leaching process of micronutrients using laboratory scale soil columns (LSSCs). Analytical Methods, 12 (8): 1131-1138. https://doi.org/10.1039/D0AY00058B

Gardner W. K. 2004. Changes in soils irrigated with saline groundwater containing excess bicarbonate. Australian Journal of Soil Research, 42: 825-831. https://doi.org/10.1071/SR03099

Gransee A., Führs H. 2013. Magnesium mobility in soils as a challenge for soil and plant analysis, magnesium fertilization and root uptake under adverse growth conditions. Plant and Soil, 368: 5-21. https://doi.org/10.1007/s11104-012-1567-y

Härdter R., Rex M., Olovius K. 2004. Effects of different Mg fertiliser sources on the magnesium availability in soils. Nutrient Cycling in Agroecosystems, 70: 249-259. https://doi.org/10.1007/s10705-004-0408-7

Huang J., Fisher P. R., Argo W. R. 2007. Container substrate$\mathrm{pH}$ response to differing limestone type and particle size. HortScience, 42: 1268-1273. https://doi.org/10.21273/HORTSCI.42.5.1268

Jones J. D. 2016. Influence of source and particle size of agricultural limestone on efficiency at increasing soil $\mathrm{pH}$. Graduate theses and dissertations, Iova State University, USA, 54 p. https://lib.dr.iastate.edu/etd/15330

Kamprath E. J., Smyth T. J. 2005. Liming. Hillel D. (ed.) Encyclopaedia of Soils in the Environment. Columbia University, USA, p. 350-358. https://doi.org/10.1016/B0-12-348530-4/00225-3

Katutis K., Rudzianskaite A. 2015. The fluctuation of calcium and magnesium concentrations in the floodwater in the Nemunas and Minija lowlands. Zemdirbyste-Agriculture, 102 (3): 257-264. https://doi.org/10.13080/z-a.2015.102.033

Kisters K., Gröber U. 2013. Magnesium in health and disease. Plant and Soil, 368: 155-165. https://doi.org/10.1007/s11104-013-1709-x

Kong X., Peng Z., Li D., Ma W., An R., Khan D., Wang X., Liu Y., Yang E., He Y., Wu L., Zhang B., Rengel Z., Wang J., Chen Q.2020. Magnesium decreases aluminum accumulation and plays a role in protecting maize from aluminum-induced oxidative stress. Plant and Soil, 457: 71-81. https://doi.org/10.1007/s11104-020-04605-1

Leda C. E., Wright R. D. 1991. Dolomitic lime particle size and container medium $\mathrm{pH}$. Journal of Environmental Horticulture, 9 (4): 226-227. https://doi.org/10.24266/0738-2898-9.4.226

Litvinovich A., Salaev I., Pavlova O., Lavrishchev A., Bure V., Saljnikov E. 2019. Utilization of large-sized dolomite by-product particles and losses of cations from acidic soil. Communications in Soil Science and Plant Analysis, 50 (7): 869-877.

https://doi.org/10.1080/00103624.2019.1589490
Litvinovich A. V., Pavlova O. Yu., Lavrishchev A. V., Bure V. M. 2020. Losses of $\mathrm{Ca}, \mathrm{Mg}, \mathrm{K}, \mathrm{Na}, \mathrm{Fe}$ and $\mathrm{F}$ from irrigated meadow-gray soil as a result of migration. Empirical models of the eluviation process (according to laboratory experience). Агрохимия, 1: 58-69 (in Russian). https://doi.org/10.31857/S0002188120010056

Liu D., Lu M., Liang Y., Chen X. 2019. Leaching and management of magnesium in typical soils of Southwest China. Presentation from the $13^{\text {th }}$ IPI-CAU-ISSAS International Symposium. https://www.ipipotash.org/13thpotash-and-polyhalite-symposium

Loganathan P., Payn T. W., Mitchell A. D., Tillman R. W. 1999. A sequential extraction method for the determination of dissolution of magnesium from fertilizers applied to pumice soils. Communications in Soil Science and Plant Analysis, 30 (1-2): 199-211. https://doi.org/10.1080/00103629909370196

Maguire M. E., Cowan J. A. 2002. Magnesium chemistry and biochemistry. BioMetals, 15: 203-210. https://doi.org/10.1023/A:1016058229972

Mehmood M., Yaseen M., Khan E. U., Khan J. M. 2018. Dolomite and dolomitization model - a short review. International Journal of Hydrology, 2 (5): 549-553. https://doi.org/10.15406/ijh.2018.02.00124

Mikkelsen R. 2010. Soil and fertilizer magnesium. Better Crops, 94 (2): 26-28. https://www.researchgate.net/ publication/308795926_Soil_and_Fertilizer_Magnesium

Mitchell A. D., Loganathan P., Payn T. W., Tillman R. W. 2000. Magnesium fertiliser dissolution rates in pumice soils under Pinus radiata. Australian Journal of Soil Research, 38: 753-767. https://doi.org/10.1071/SR99083

Oliveira M. W., Trivelin P. C. O., Boaretto A. E., Muraoka T., Mortatti J. 2002. Leaching of nitrogen, potassium, calcium and magnesium in a sandy soil cultivated with sugarcane. Pesquisa Agropecuária Brasileira, 37 (6): 861-868. https://doi.org/10.1590/S0100-204X2002000600016

Pavlova O., Litvinovich A., Lavrishchev A., Bure V., Saljnikov E. 2019. Eluvial losses of $\mathrm{Ca}$ from Umbric Albeluvisols Abruptic produced by different doses of lime: column experiment. Zemljiste i Bilika, 68 (2): 1-12. https://doi.org/10.5937/ZemBilj1901001P

Rosanoff A., Kumssa D. B. 2020. Impact of rising body weight and cereal grain food processing on human magnesium nutrition. Plant and Soil, 368: 139-153. https://doi.org/10.1007/s11104-020-04483-7

Rowley M. C., Grand S., Adatte T., Verrecchia E. P. 2020. A cascading influence of calcium carbonate on the biogeochemistry and pedogenic trajectories of subalpine soils, Switzerland. Geoderma, 361: 114065. https://doi.org/10.1016/j.geoderma.2019.114065

Royani A., Sulistiyono E., Prasetiyo A. B., Subagja R. 2018. Extraction of magnesium from calcinied dolomite ore using hydrochloric acid leaching. AIP Conference Proceedings, 1964: 020017. https://doi.org/10.1063/1.5038299

Sekine Y., Motokawa R., Kozai N., Ohnuki T., Matsumura D., Tsuji T., Kawasaki R., Akiyoshi K. 2017. Calcium-deficient hydroxyapatite as a potential sorbent for strontium. Scientific Reports, 7: 2064. https://doi.org/10.1038/s41598-017-02269-Z

Senbayram M., Gransee A., Wahle V., Thiel H. 2015. Role of magnesium fertilizers in agriculture: plant-soil continuum. Crop and Pasture Science, 66 (12): 1219-1229. https://doi.org/10.1071/CP15104

Shilnikov I., Akanova N., Marenkova M., Okorkov V., Okorkova L., Fenova O. 2013. Loss of exchangeable cations and soil acidification with long-term use of fertilizers. 
Scientific bases to prevent soil (land) degradation of Russian agricultural lands and the formation of systems of reproduction of their fertility in adaptive-landscape farming (proceedings), p. 351-386 (in Russian).

Wang Z., Hassan M. U., Nadeem F., Wu L., Zhang F., Li X. 2020. Magnesium fertilization improves crop yield in most production systems: a meta-analysis. Frontiers in Plant Science. 10: 1727.

https://doi.org/10.3389/fpls.2019.01727

Wei X., Liu S., Müller K. Song Z., Guan G., Luo J., Wang H. 2019. Urbanization-induced acid rain causes leaching loss of calcium from limestone-derived soil in South China. Journal of Soils and Sediments. 19 (11): 3797-3804.

https://doi.org/10.1007/s11368-019-02324-4
WRB. 2015. World reference base for soil resources. World soil resources reports No. 106, $192 \mathrm{p}$.

Yan B., Hou Y. 2018. Effect of soil magnesium on plants: a review. IOP Conference Series: Earth and Environmental Science. 170: 022168. https://doi.org/10.1088/1755-1315/170/2/022168

Zelenov N., Shilnikov I., Akanova R., Shvyrkov D. 2010. Reserve of chemical ameliorants and their agro-ecological effectiveness. Contemporary problems and prospects of soil lime. St. Petersburg, Russia, p. 30-34 (in Russian).

\title{
Magnio išplovimas iš velèninio jaurinio priesmẻlio, papildyto smulkiai sumaltu dolomitu
}

\author{
A. Litvinovich ${ }^{1}$, O. Pavlova ${ }^{1}$, A. Lavrishchev ${ }^{2}$, V. Bure ${ }^{1,3}$, E. Saljnikov ${ }^{4,5}$ \\ ${ }^{1}$ Rusijos agrofizikinių tyrimų institutas \\ ${ }^{2}$ Sankt Peterburgo valstybinis universitetas, Rusija \\ ${ }^{3}$ Sankt Peterburgo valstybinis žemès ūkio universitetas, Rusija \\ ${ }^{4}$ Serbijos dirvožemio mokslo institutas \\ ${ }^{5}$ Mitscherlich dirvožemio derlingumo akademija, Vokietija
}

\section{Santrauka}

Pateikti rezultatai aštuonių keičiamų / reguliuojamų kolonėlių eksperimento, vykdyto labai rūgščiame velèniniame jauriniame priesmėlyje, papildytame įvairiomis dozėmis smulkiai sumalto dolomito. Tyrimo tikslas - išmatuoti ir įvertinti magnio $(\mathrm{Mg})$ išplovimą ir jo migracijos pobūdį. Eksperimente naudotos susmulkinto dolomito dozės buvo apskaičiuotos pagal hidrotinị rūgštumą (Hy): 225, 337,5, 450, 675, 900, 1350 ir $1800 \mathrm{mg}$, kurios atitinka 0,5, 0,75, $1,0,1,5,2,0,3,0$ ir 4,0 Hy. Magnio migracija buvo tirta 12 kartų vykdant jo išplovimo iš kolonèlių eksperimentą. Išplovimas buvo atliktas naudojant $400 \mathrm{ml}$ distiliuoto vandens, imituojant ị dirvožemio sluoksnị prasiskverbiančių metinių kritulių kiekį. Magnio išplovimo iš dirvožemio eliuvinio sluoksnio padidèjimą lèmè gilyn pratekèjusio vandens kiekis. Dėl migracijos didžiausias Mg išplovimas nustatytas eksperimento pirmojo etapo filtratuose. Didinant dolomito dozę, migruojantis Mg kiekis sumažėjo nuo 27 iki 7,5\%. Vandenyje tirpus Mg iš dirvožemio nebuvo visiškai išplautas taikant né vieną iš tirtų metodų. Pateiktos empirinès priklausomybès, kurios apibūdino $\mathrm{Mg}$ išplovimo procesą iš dirvožemio pakartotinių išplovimų metu. Remiantis iš dirvožemio išplauto Mg tyrimo duomenimis, buvo atliktas empirinių lygčių grupavimas. Nustatyta, kad eksperimento pirmajame etape (nuo 1 iki 4 plovimų) padidinus dolomito dozę, Mg išplovimo greitis žymiai padidejo. Antrajame etape (nuo 4 iki 12 plovimų) toks išplovimo pobūdis nenustatytas. Priklausomai nuo dolomito dozès, Mg nuostoliai padidejjo nuo 14,05 iki $50,6 \mathrm{mg}$, palyginti su 3,8 mg nekalkintame (kontroliniame) variante.

Nustatyta, kad susmulkinto dolomito kiekis, viršijantis pilną dozę, apskaičiuotą pagal $1 \mathrm{Hy}$, ịterptas ị velèninị jaurinị miško dirvožemị, buvo nuostolingas; tai reiškia, kad didinant dolomito dozę didejo ir išplaunamo $\mathrm{Mg}$ kiekis.

Reikšminiai žodžiai: empirinis vertinimas, grupavimas, išplovimo greitis, magnis, migracija. 